\title{
Efektivitas Model Huntara Paska Gempabumi Sulawesi Tengah 2018: Studi Kasus Huntara di Kabupaten Sigi
}

\author{
Muhammad Andriansyah ${ }^{1}$, Noor Cholis Idham ${ }^{2}$ \\ ${ }^{1,2}$ Universitas Islam Indonesia, Indonesia \\ Email: noor.idham@uii.ac.id
}

\begin{abstract}
INFORMASI ARTIKEL
Abstract: The Central Sulawesi earthquake in September 2018 destroyed most of areas including Sigi Regency which was the most affected with a total housing requirement of 13,144 units. In the transition phase, there were 43 institutions involved in the fulfillment of shelters, but the approach and implementation had differences, thus affecting the quality and response of survivors. The purpose of this study was to determine the effectiveness of shelters based on the concept and implementation approach of the aid providers, namely the Ministry of PUPR, CRS, Habitat, and KUN. The effectiveness level was measured descriptively by comparing approaches and survivor responses from each institution which showed that the participatory cash-based individual shelter model approach was more effective in the transition phase and collective shelters were effective in the emergency phase.
\end{abstract}

Keywords: Transitional phase, shelter concept, implementation, survivor response, aid agency

\begin{abstract}
Abstrak: Gempabumi Sulawesi Tengah September 2018 menghancurkan sebagian besar wilayah termasuk kabupaten Sigi yang paling terdampak dengan total kebutuhan hunian 13.144 unit. Pada fase transisi terdapat 43 lembaga terlibat pemenuhan huntara, namun pendekatan dan implementasinya memiliki perbedaan, sehingga mempengaruhi kualitas maupun respon penyintas. Tujuan penelitian ini untuk mengetahui efektivitas huntara berdasarkan pendekatan konsep dan implementasi dari lembaga pemberi bantuan yaitu kementrian PUPR, CRS, Habitat, dan KUN. Tingkat efektivitas diukur secara deskriptif komparasi pendekatan dan respon penyintas dari tiap lembaga yang menunjukkan pendekatan model huntara mandiri berbasis uang tunai partisipatif lebih efektif di fase transisi dan huntara kolektif efektif di fase darurat
\end{abstract}

Kata Kunci: Fase transisi, konsep huntara, implementasi, respon penyintas, lembaga pemberi bantuan

Article history:

Received ; 2021-08-12

Revised ; 2021-08-29

Accepted; 2021-09-23

\section{PENDAHULUAN}

Gempabumi Sulawesi Tengah 2018 dengan magnitude 7.7 SR, kedalaman 10 km, jarak 26 kilometer utara kabupaten Donggala telah memicu kerusakan dan gelombang tsunami dengan ketinggian 0.5m hingga 3m (BMKG, 2018:1). Gempa ini juga mengakibatkan likuifaksi sehingga bangunan yang berada di atasnya bergerak dan hancur (Badan Geologi, 2018:5). Dampak bencana disejumlah wilayah Kota Palu, Kabupaten Sigi, Donggala, dan Parigi Mautong. Kerusakan tertinggi terdapat di Kabupaten Sigi dengan kerusakan berat hunian hingga12.842 unit serta jumlah pengungsi mencapai 93.187 jiwa (Pemerintah Provinsi Sulawesi Tengah, 2019:6-8). Dampak ini membuat pemerintah daerah tidak dapat mengakomodasi keseluruhan area bencana, tentu saja ini menimbulkan kerentanan penyintas. Kehilangan rumah juga berarti kehilangan martabat seseorang, identitas, dan privasi, yang pada akhirnya meningkatkan penyakit dan polusi (Bashawri et al, 2014:930).

Paska fase darurat yang hanya mengandalkan tenda atau terpal untuk hunian darurat, maka selanjutnya pemenuhan hunian sementara (huntara) di fase transisi. Pemenuhan huntara tidak hanya mengandalkan kecepatan, namun juga harus dapat bertahan selama kurun waktu 
yang dibutuhkan berkisar 1-2 tahun (Forouzandeh et al, 2008:1). Huntara juga harus aman, nyaman dan bermartabat agar dapat membantu proses pemulihan korban bencana dari rasa trauma dan pemulihan ekonomi bagi para penyintas (Barakat, 2003:1, Batchelor, 2011:51, The Sphere Project, 2011:255, Donohou, 2012:2). Penyediaan huntara dengan pendekatan yang kurang tepat juga dapat menimbulkan biaya yang banyak, kualitas buruk dan waktu keterlambatan distribusi (Da Silva, 2010:16), dan ini dapat berpotensi kerentanan bagi penyintas.

Pemenuhan huntara bukan sekedar produk siap pakai yang didistribusikan, melainkan sebuah proses bekerja sama dengan komunitas, pendampingan, sejalan dengan efisiensi dan pembiayaan yang efektif (PMI, 2019:2.4). Meskipun menjadi faktor penentu pemulihan bencana, namun pendekatan konsep hunian masih banyak yang belum merespon sesuai konteks bencana dan kondisi lokasi (Bashawri et al, 2014:929), (Félix et al, 2013:10). Kondisi iklim serta cuaca juga dapat mempengaruhi kesehatan penyintas (Wu et al, 2019:1-2) sehingga tingkat kenyamanan pengungsi pada lingkungan hunian sementara menjadi sangat penting (Thapa et al, 2018:342).

Terkait pendekatan, Doocy (et al, 2006:293) menerangkan pada bencana gempa dan tsunami Aceh bahwa pendekatan partisipatif melalui cash for work (CFW) memberikan kontribusi yang lebih signifikan dalam pemulihan ekonomi keluarga dalam mewujudkan hunian permanen seperti sediakala. Sementara, Faure Walker \& Anna Crawford (2017:229) pada bencana gempa bumi di Jepang menyatakan bahwa bantuan uang tunai tidak dirancang untuk mengatasi krisis hunian paska bencana karena sifatnya darurat. Menurut Leon (et al, 2009:247) berdasarkan 23 kasus, parameter utama hunian sementara adalah keselamatan, keamanan, dan mata pencaharian, transisi menuju hunian permanen, keadilan, kesetaraan, dan kerentanan. Wulansari (2017:92-93) menyampaikan kualitas hunian paska bencana dapat dilihat dari aspek struktur hunian, aspek desain hunian, aspek kenyamanan fisik, aspek fungsional, maupun keterlibatan masyarakat dalam proses pengadaan hunian. Félix (2013:141) juga menambahkan perlunya perencanaan hunian sementara yang efektif mengingat perubahan iklim dan bencana akan terus terjadi.

Pertimbangan pada perilaku pengguna dapat menjadi acuan dasar konsep hunian sementara agar dapat dikembangkan menjadi hunian permanen (Hindami et al, 2014:35). Sementara dampak ketidakpuasan pengadaan telah menimbulkan adanya pengembangan mandiri sebagai bentuk adaptasi pengguna (Wulansari, 2014:27). Respon pengguna berdasarkan pengalaman ruang yang tidak bisa digeneralkan menjadi hal yang sangat penting dalam pencapaian hunian sementara yang efektif. Konstribusi masyarakat terhadap harapan dan keinginan huniannya tidak hanya menghasilkan penurunan biaya proyek, tetapi juga mengurangi waktu konstruksi (Forouzandeh, et al. 2008:8).

Hal ini juga berhubungan keputusan pengunaan material pada model huntara yang cukup beragam baik fabrikasi maupun bahan lokal yang dapat mempengaruhi proses pemulihan baik secara fisik maupun psikologi (Yu et al, 2016:174). Pada dasarnya dari material fabrikasi dan lokal sama-sama memiliki performa baik tergantung konteks lokasi dan kebutuhan. Material fabrikasi memiliki kecepatan pemasangannya, mudah didapat dan murah sementara menurut Zea Escamilla \& Habert (2015:692) bahwa material lokal dapat menahan dampak lingkungan dan biaya rendah sedangkan material industrial untuk menghasilkan kinerja teknis yang lebih baik. Dari sisi implementasi, pemerintah dan NGO menjadi aktor penting dalam pemenuhan huntara pada setiap kasus bencana (Carrasco \& O'Brien, 2018:612).

Terdapat 43 lembaga kemanusiaan terlibat dalam program pemenuhan huntara di Kabupaten Sigi yang terdiri dari lembaga pemerintah dan LSM lokal maupun internasional yang biasa disebut juga Non-Governmental Organization (NGO). Hingga 20 Desember 2019, dari total kebutuhan Huntara 13.144 unit, terdapat 12.357 unit yang sudah terlaksana, dan 
belum terlaksana 787 unit (Sub Shelter Klaster Sulteng, 2019:17) sementara fase transisi telah berakhir semenjak 24 April 2019 (Kareba Palu Koro, 2019:2). Selain itu, konsep dan implementasi dari lembaga memiliki perbedaan yang cukup signifikan sehingga mempengaruhi kualitas huntara baik yang kolektif atau mandiri . Survey yang dilakukan Community Engagement Working Group (CEWG), bahwa keprihatinan yang paling tinggi dari penyintas tentang keselamatan dan keamanan agar fasilitas huntara kolektif dipisahkan sesuai gender dengan ruangan terpisah (Buletin suara komunitas, 2018:1). Pada beberapa kasus juga terdapat unit huntara mandiri hanya dijadikan penyimpanan barang. Hal ini menggambarkan adanya ketidaksesuaian model huntara sehingga tidak efektif untuk memulihkan penyintas dari keterpurukan.

Pembahasan terkait huntara telah banyak dilakukan dan hanya terfokus pada satu (1) lembaga, sehingga sulit untuk mengetahui efektivitas dari model huntara tersebut, maka penilitian ini akan membahas pendekatan dari empat (4) lembaga (Kementrian PUPR, CRS, KUN Humanity, dan Habitat for Humanity) yang memiliki perbedaan signifikan baik dari segi konsep maupun implementasinya serta respon penyintas. Tujuan penelitian ini untuk mengetahui efektivitas huntara selama fase transisi berdasarkan empat (4) kasus model huntara di Kabupaten Sigi. Penelitian ini nantinya dapat memberikan rekomendasi model huntara dan evaluasi bagi lembaga kemanusiaan dalam program huntara di fase transisi khusus bagi pemerintah dalam mewujudkan ketahanan kebencanaan di Indonesia.

\section{METODE PENELITIAN}

Metode kualitatif digunakan agar mengetahui secara mendalam terhadap model huntara, meliputi pendekatan konsep model dan implementasi dari masing-masing lembaga. Peneliti melakukan pengumpulan data secara mendetail menggunakan berbagai prosedur pengumpulan data dalam waktu yang berkesinambungan, sedangkan metode kuantitatif digunakan untuk mengetahui ragam respon penyintas dari masing-masing lembaga melalui kuisioner (Hamidi dalam Supriyati, 2015:5-6). Menentukan jumlah responden dengan cara pengambilan sampling unit huntara berdasarkan penjelasan Suharsimi Arikunto (2006) dalam (Hatmoko, 2015) jika subyek besar (lebih dari 100) maka pengambilan samplingnya dapat 20\%-25\% atau lebih (tabel 1).

Dari 43 lembaga kemanusiaan yang terlibat pemenuhan huntara di Kabupaten Sigi, maka dilakukan pemilahan lembaga berdasarkan kriteria yang ditentukan. Kriteria yang ditentukan bertujuan untuk mewakili tipologi huntara dari keseluruhan lembaga yaitu (1) Jumlah Huntara yang terlaksana minimal 500 unit dan lembaga mendampingi proses pelaksanaan, (2) Memiliki kekhususan konsep model dan material, (3) Memiliki pengalaman pemenuhan huntara pada kasus bencana yang berskala nasional maupun internasional, (4) Aktif menjalin kordinasi dalam forum Sub Klaster Shelter, dan (5) Lembaga pelaksana yang memiliki manajemen yang baik dan aktif dalam ikut serta menangani bencana yang terjadi di Indonesia. Dari hasil pemilahan, terdapat empat (4) lembaga yang memenuhi kriteria yakni Kementrian PUPR, Catholic Relief Services (CRS), Habitat for Humanity (HFH), KUN Humanity (gambar 1). 


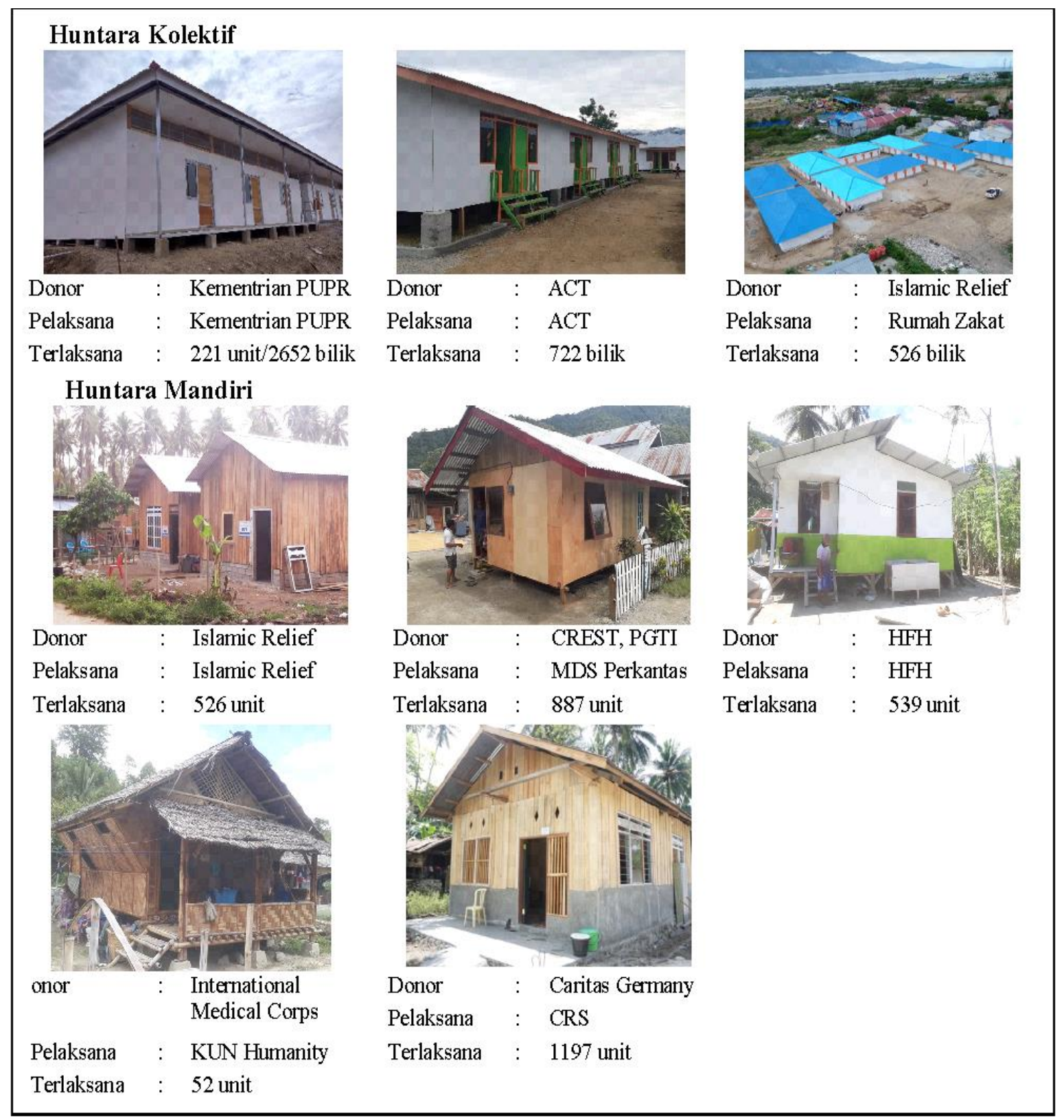

Gambar 1. Model Huntara dari masing-masing lembaga yang masuk kriteria.

Penyajian dilakukan dengan analisis secara deskriptif komparasi dari tiap lembaga dan respon penyintas sehingga dapat menilai tingkat efektivitas. Adapun respon penyintas mengacu pada tingkat kebutuhan manusia melalui instrument kuisioner yang didalamanya terdapat 3 indikator yaitu:

1) Respon terhadap kebutuhan bertempat tinggal sementara, Penekanan pada indikator ini, bahwa respon yang dirasakan penyintas akan kebutuhan huniannya yang bersifat sementara pada fase darurat menuju transisi. Bagian ini terdiri tiga variabel yaitu pemenuhan terhadap bertempat tinggal, tertampungnya seluruh anggota keluarga, dan tertampungnya seluruh barang di huntara.

2) Respon terhadap rasa aman dan nyaman, Penekanan berkaitan pengalaman saat menghuni huntara selama fase transisi. Variabel pada bagian ini adalah rasa selamat 
dan aman terhadap bencana berikutnya, rasa aman dalam melindungi harta benda di huntara, serta rasa nyaman selama tinggal di Huntara.

3) Harapan terhadap Huntara, Penekanan berkaitan harapan penyintas terhadap konsep huntara. Adapun variabel yang didalamnya adalah keselamatan, keamanan, kenyamanan, dan aspek sekunder hunian.

\section{HASIL DAN PEMBAHASAN \\ Pendekatan Konsep Huntara dan Implementasi dari Kementrian PUPR}

Konsep huntara yang digunakan di Provinsi Sulawesi Tengah merupakan hasil dari penyempurnaan pada kasus bencana gempa bumi di Provinsi Nusa Tenggara Barat 2018. Dalam merespon fase darurat menuju transisi yang membutuhkan kecepatan, maka konsep huntara Kementrian PUPR seluruhnya menggunakan pabrikasi agar efesien dan efektif dalam pelaksanaan (gambar 2).

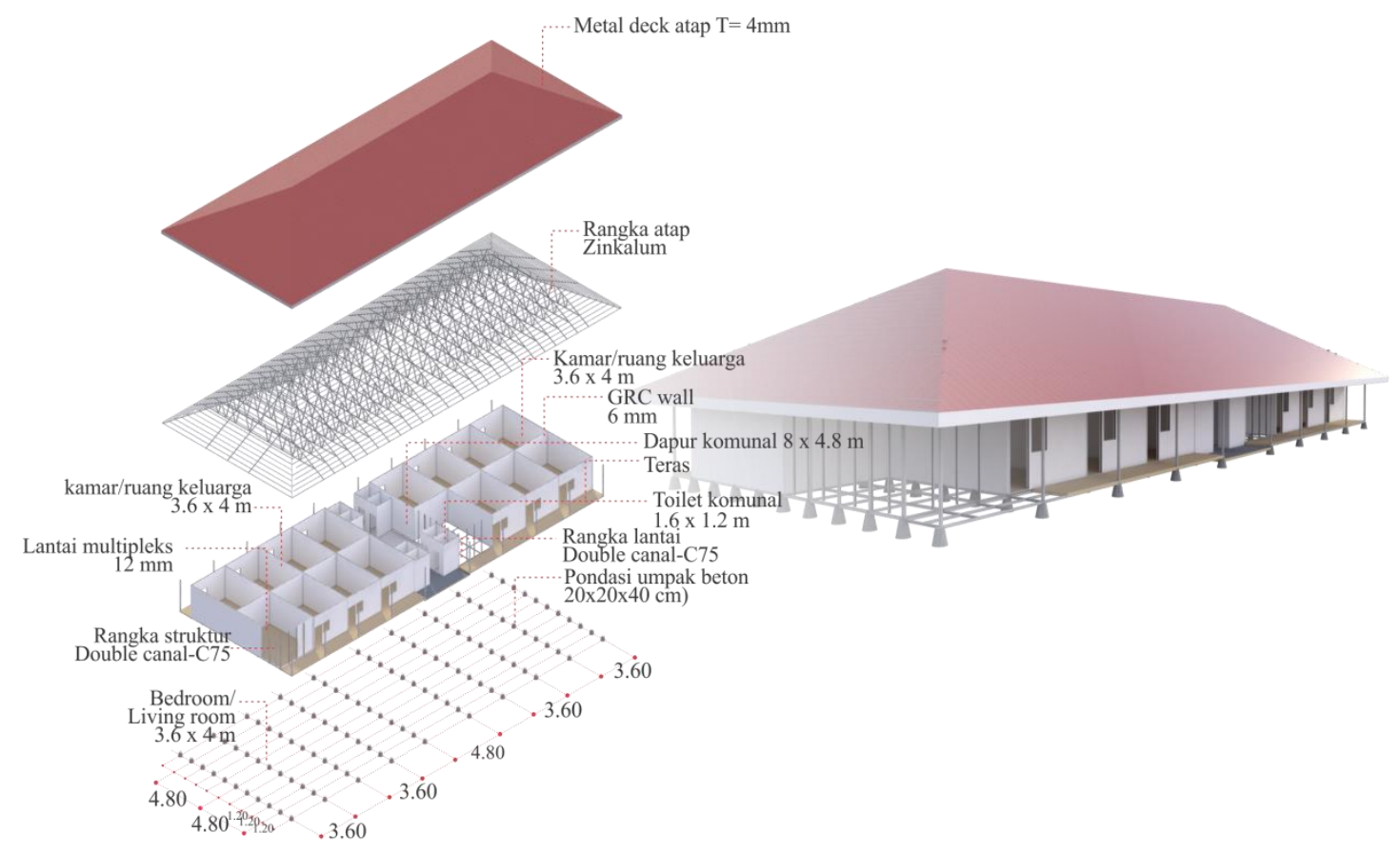

Gambar 2. Model huntara kolektif Kementrian PUPR (sumber: PUPR)

Model huntara bersifat kolektif atau komunal terdiri dari ruang-ruang huni untuk keluarga dan fasilitas umum yang terletak di bagian tengah berupa dapur, ruang cuci, dan kamar mandi. Unit bangunan ini berukuran $12 \mathrm{~m}$ x 26,4 m yang dibagi menjadi 12 bilik berukuran 3,6 m x 4,8 m. Huntara ini telah terintegrasi dalam satu kawasan yang dilengkapi fasilitas pendukung. Sistem sturuktur yang digunakan adalah rangka baja ringan dengan pondasi umpak panggung. Bentuk huntara PUPR mengikuti bentuk konvensional banguna tropis dengan bentuk atap pelana agar mudah dalam pengerjaan dan sifatnya yang hanya sementara. Secara keseluruhan aspek arsitektural dalam mencapai kenyamanan ruang berpotensi tidak tercapai maksimal yang disebabkan sirkulasi bukaan tidak mendukung. Hal ini berhubngan dengan konsep bentuk huntara yang komunal sehingga sulit untuk menempatkan cross ventilation.

Dalam tahap perencanaan desain huntara Kementrian PUPR melakukan kemitraan bersama konsultan Badan Usaha Milik Negara (BUMN) sedangkan tahap pelaksanaan bermitra dengan kontraktor BUMN (gambar 3). Penentuan lokasi disesuaikan dengan konsep 
huntara yang membutuhkan area yang luas dan penggunaan lokasi berdurasi dua (2) tahun dengan sistem sewa lahan. Lokasi ditentukan berdasarkan daerah yang terdampak bencana dan tidak berada di zona merah Peta Rawan Bencana (PRB). Fakta di lapangan terkadang sulit mencari area yang sesuai komitmen antara pemilik tanah dan pihak Kementrian PUPR. Akibatnya dibeberapa kasus, pemilihan lokasi huntara berpotensi banjir. Selain itu pemilihan lokasi juga terkadang tidak sesuai dengan harapan warga sehingga tidak dihuni namun hanya dijadikan penyimpanan barang.

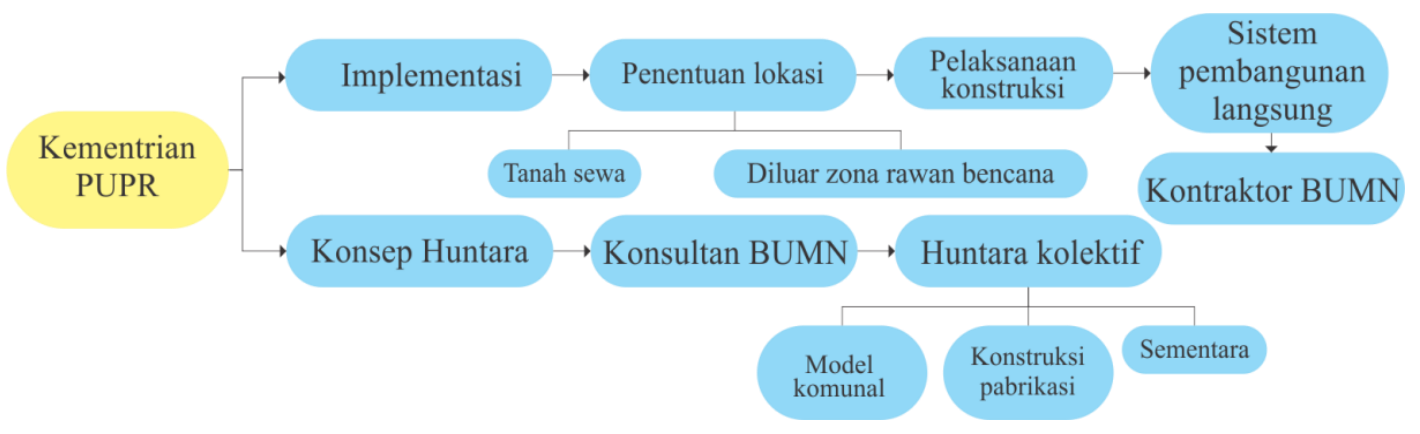

Gambar 3. Tahapan pendekatan dan implementasi Kementrian PUPR

Pelaksanaan pembangunan satu unit huntara membutuhkan waktu antara 3-4 minggu. Kendala yang dihadapi yaitu terbatasnya material di lokasi pembangunan sehingga pemesanan material dari luar Provinsi Sulawesi Tengah, dan terbatasnya tenaga ahli pemasangan rangka baja ringan sehingga pihak kontraktor mendatangkan tukang dari luar Provinsi Sulawesi Tengah.

\section{Pendekatan Konsep Huntara dan Implementasi dari Lembaga Catholic Relief Service (CRS)}

Paska pemenuhan shelter darurat di fase darurat, kemudian CRS melakukan indepth assessment untuk program huntara dalam memasuki fase transisi. CRS langsung berkordinasi dengan pihak pemerintah dan sub klaster secara sektoral khususnya terkait kebutuhan hunian. Dari hasil kordinasi tersebut bahwa pemerintah menyatakan kesanggupan dalam pemenuhan hunian tetap atau huntap bagi penyintas sehingga CRS memilih pendekatan model bantuan huntara yang dapat digunakan sebelum terbangunnya huntap. Total huntara CRS yang terbangun 1.142 unit, salah satunya di Desa Omu Kecamatan Gumbasa sebagai obyek penelitian. 


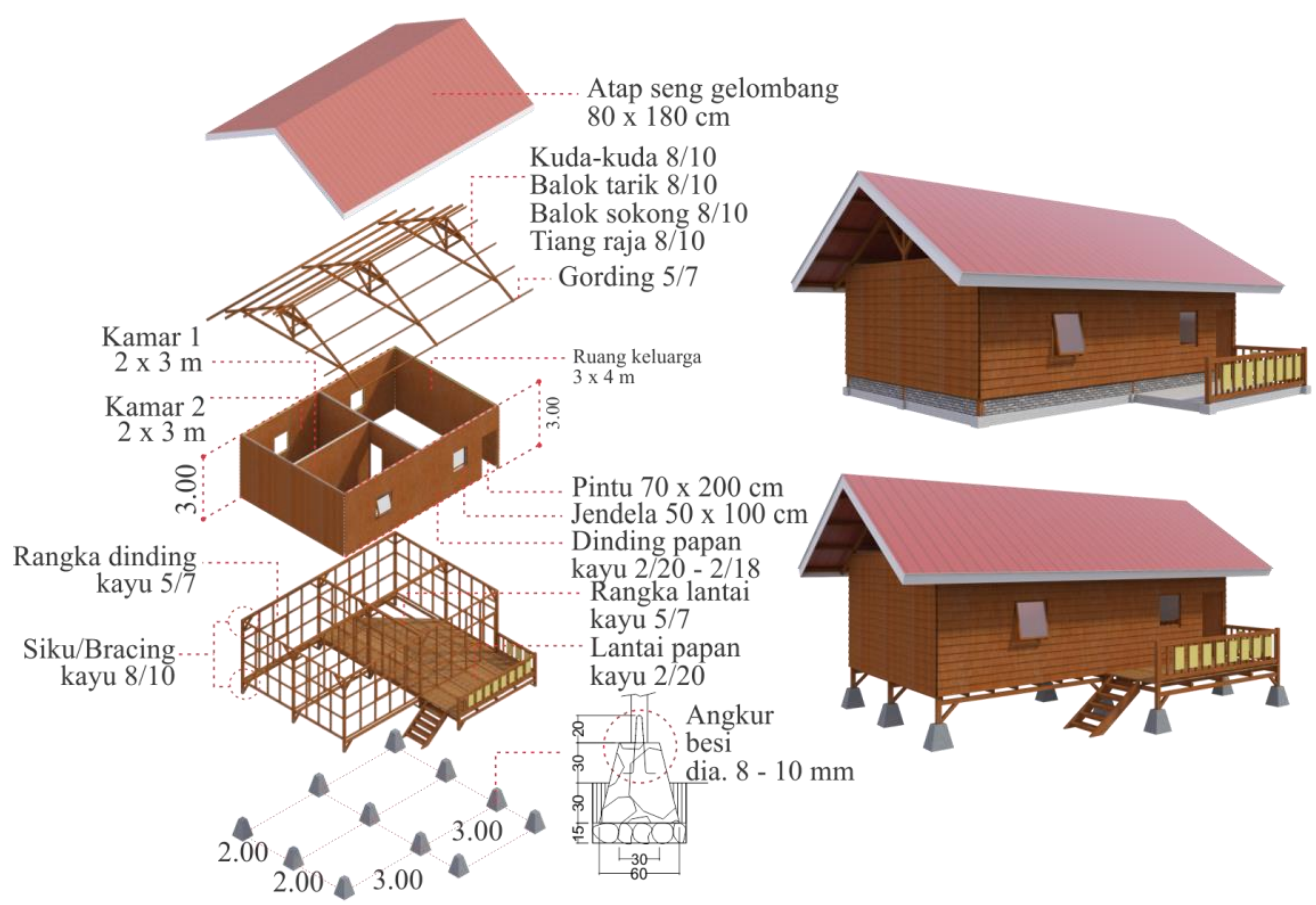

Gambar 4. Model huntara mandiri CRS (sumber: CRS)

Konsep hunian yang digunakan oleh CRS bersifat mandiri atau individu yang dapat tumbuh di lahan sendiri. Pendekatan konsep huntara secara partisipatif dilakukan dengan cara bantuan uang tunai senilai Rp. 15.000.000 berdasarkan analisa perencanaan yang disesuaikan konteks lokasi bantuan. Potensi material kayu di Desa Omu menjadi dasar perencanaan konsep huntara. Model huntara CRS memiliki luasan dominan menggunakan rangka kayu dengan ukuran $4 \mathrm{~m}$ x $6 \mathrm{~m}$ (gambar 4). Penyintas dapat leluasa dalam mengelola keuangan dan membangun huniannya yang disesuaikan bantuan tunai, sehingga mengakomodasi kebutuhan keluarga khususnya kebutuhan ruang. Struktur bawah, tengah, dan atas menjadi perhatian CRS dalam memonitoring pelaksanaan pembangunan. Pada kasus tanah pinjaman, CRS menawarkan konsep hunian menggunakan sistem panggung atau knock down.

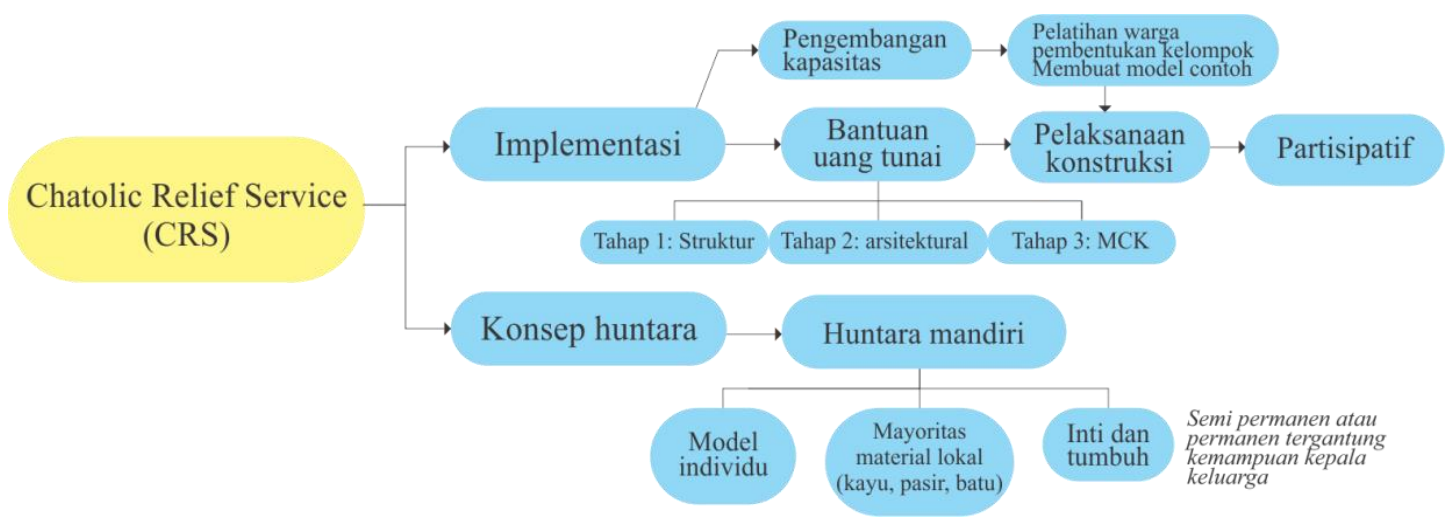

Gambar 5. Tahapan pendekatan dan implementasi lembaga CRS

Dalam implementasinya, CRS membuat mekanisme kelompok dengan tujuan agar terjadinya rasa gotong-royong antar warga serta sebagai sistem monitoring sehingga ada beban moral untuk tetap bertanggung jawab atas bantuan yang diberikan (gambar 5). Pembagian kelompok berdasarkan dusun yang terdiri dari beberapa rukun tetangga (RT), 
kemudaian dikerucutkan menjadi satu lingkup area yang berkelompok. Jumlah anggota perkelompok terdiri dari minimal 5 orang dan maksimal 10 orang/KK. Mekanisme kelompok ini dilakukan semenjak pendistribusian uang tunai tahap pertama hingga proses pelaksanaan pembangunan huntara. Setiap kelompok wajib memiliki perwakilan tukang dan saling memonitoring proses pelaksanaan. Pada pelaksanaan pembangunan apabila terdapat salah satu penerima yang memiliki keterlambatan progress, maka semua anggota kelompok belum berhak menerima distribusi tunai tahap selanjutnya.

Pelaksanaan pembangunan umumnya mengikuti perencanaan model CRS dengan ukuran $4 \mathrm{~m} \times 6 \mathrm{~m}$, namun terdapat warga yang melakukan perubahan luasan ruang menjadi $4 \mathrm{~m}$ $\mathrm{x} 7 \mathrm{~m}$ atau $5 \mathrm{~m} \times 7 \mathrm{~m}$ dan seterusnya. Hal ini dipengaruhi kemampuan pengelolaan dan finansial dari keluarga pengguna. Pemanfaatan material kayu sisa bangunan sebelumnya juga terlihat digunakan oleh beberapa keluarga atau pembelian keseluruhan material khususnya penyintas perempuan rentan yang tidak memiliki keluarga.

Alokasi waktu yang direncanakan CRS adalah tiga bulan namun penyelesaian konstruksi dari tiap keluarga bervariasi dapat satu (1) bulan hingga lima (5) bulan. Bahkan dalam beberapa kasus tidak dapat menyelesaikan. Penyebab penyelesaian yang bervariasi adalah kebutuhan sehari-hari yang mendesak dari beberapa keluarga, sehingga terpaksa menggunakan uang bantuan tunai dari CRS sehingga mempengaruhi kefektifan program yang disusun oleh CRS. Pendekatan ini cukup memberikan tantangan bagi CRS dalam memonitoring pelaksanaan terutama pada kelompok penerima bantuan dengan kinerja rendah.

\section{Pendekatan Model Huntara Lembaga Habitat for Humanity}

Pada kasus gempa di Provinsi Sulawesi Tengah, Habitat terlibat respon bencana pada fase darurat, fase transisi, dan fase rehabilitasi. Pada fase transisi total huntara yang dibangun Habitat sebanyak 512 unit yang terdistribusi di tujuh desa pada kecamatan Dolo Selatan, salah satunya Desa Wisolo sebagai objek penelitian. Berdasarkan hasil kordinasi dan observasi pada saat fase darurat, Habitat memilih lokasi yang terdampak rusak parah, yaitu Desa Wisolo. Pengungsi di Desa Wisolo sedikit berbeda dengan pengungsi desa lain yang terpusat di lapangan. Warga Wisolo memilih mendirikan tenda pengungsiannya di lokasi perkebunan milik warga yang masih produkif. Di area pengungsian terdapat perkebunan coklat yang mempunyai jarak antar pohon 5-6 m yang tidak diperbolehkan untuk ditebang, maka Habitat, pejabat desa serta pemilik tanah melakukan perjanjian tertulis untuk penggunaan lahan, sehingga penyintas merasa nyaman saat tinggal di huntara.

Pendekatan yang dilakukan Habitat berdasarkan konteks lokasi yang bersifat privat, sehingga menjadi dasar konsep huntara bersifat tidak permanen dengan sistem panggung yang berukuran $4 \mathrm{~m} \times 5 \mathrm{~m}\left(20 \mathrm{~m}^{2}\right)$ yang terdiri dari teras, kamar tidur dan ruang keluarga (Gambar 6). Model Huntara dominan menggunakan material baja ringan. Pemilihan material baja dipengaruhi oleh karena sebagian besar wilayah Kabupaten Sigi adalah wilayah konservasi dan Desa Wisolo secara keseluruhan dipenuhi kebun kelapa. Apabila material kayu kelapa dominan digunakan maka akan mempengaruhi mata pencaharian penerima manfaat sendiri, maka baja ringan menjadi alternatif terakhir sebagai struktur tengah dan atas sedangkan untuk struktur bawah menggunakan kayu kelapa. 


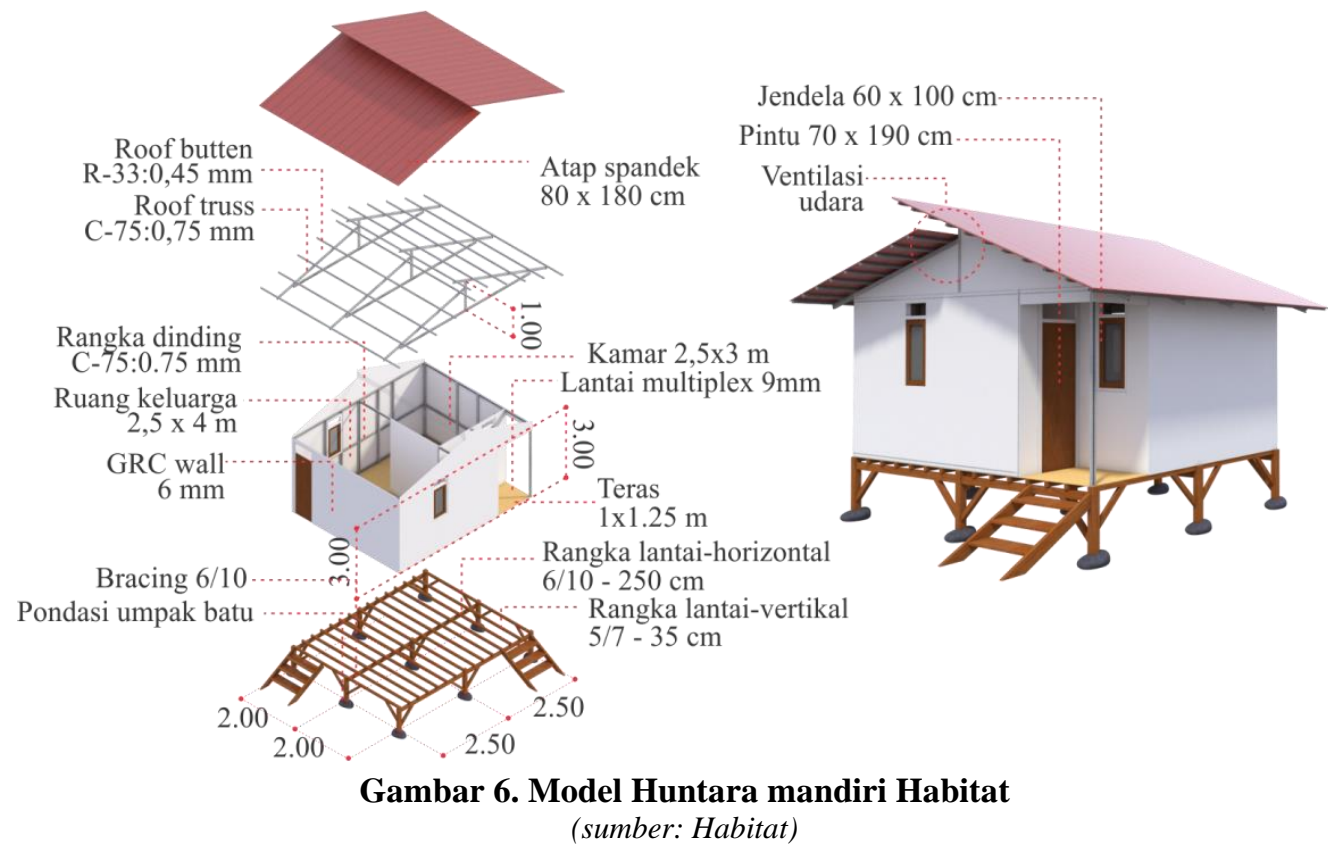

Dalam implementasinya, Habitat mendistribusikan bantuan dengan cara bantuan material serta tahapan penguatan kapasitas dengan melakukan pelatihan tukang konstruksi baja ringan dengan membentuk kelompok tukang dari perwakilan tiap keluarga (Gambar 7). Hal ini membutuhkan proses dan menjadi hal yang baru bagi penerima manfaat, yang sebelumnya hanya mengetahui konstruksi kayu. Harapannya warga nantinya akan mempunyai keahlian berbeda selain berkebun yang mengalami gagal panen akibat gempa.

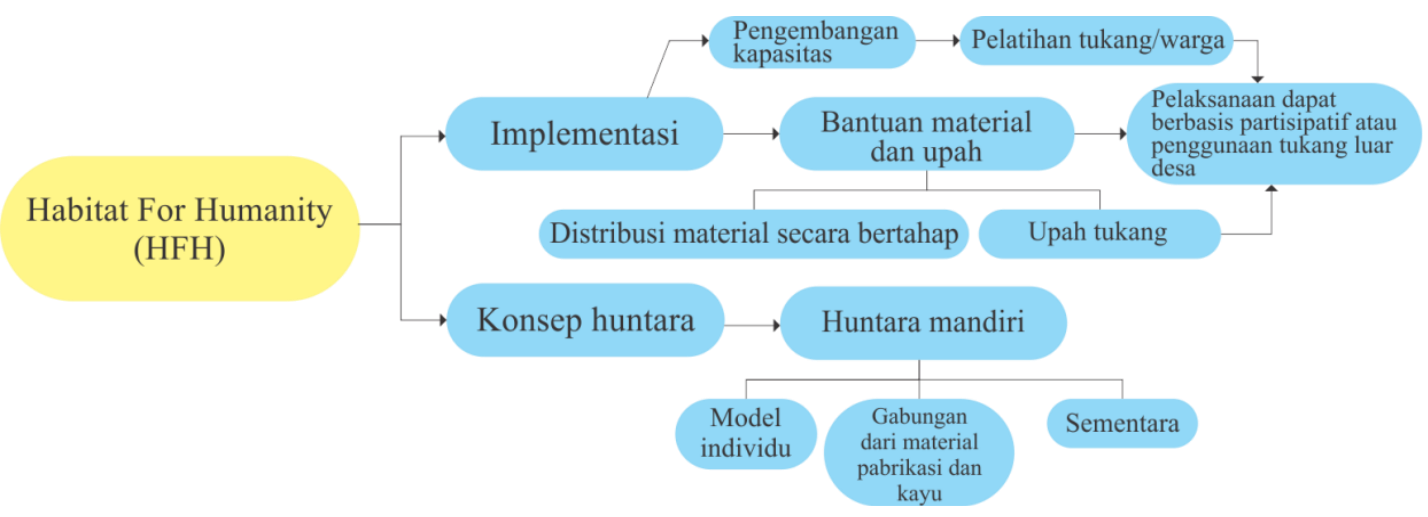

Gambar 7. Tahapan pendekatan dan implementasi lembaga Habitat

Proses pelaksanaan dengan cara membagikan material sesuai spesifikasi model huntara secara bertahap sesuai data final penerima manfaat. Pengerjaan mayoritas dilaksanakan oleh masing-masing kepala keluarga yang sebelumnya mengikuti pelatihan tukang konstruksi baja, lama pengerjaan konstruksi yakni 10-14 hari. Semua model Huntara memiliki perencanaan yang sama, namun pada pelaksanaannya menghasilkan ragam tata letak ruang, seperti penempatan kamar atau teras sesuai keinginan pemilik Huntara. Pada penataan ruang, beberapa pemilik kesulitan dalam menempatkan ruang dapur untuk menyatu dengan ruang lain yang akhirnya hanya digunakan tempat istirahat dan menyimpan harta benda. 


\section{Pendekatan Konsep Huntara dan Implementasi dari Lembaga KUN Humanity}

Pada kasus bencana Provinsi Sulawesi Tengah 2018, KUN Humanity yang didukung International Medical Corps (IMC) ikut serta dalam program pemenuhan huntara. Lokasi sasaran yang dipilih adalah desa Namo dikecamatan Kulawi kabupaten Sigi dengan jumlah keluarga yang terdampak sebanyak 52 kepala keluarga. KUN menggagas konsep huntara berbahan bambu dengan tujuan untuk mengembalikan kebudayaan bambu yang telah lama berperan dan menyatu bersama kehidupan masyarakat desa Namo. KUN melakukan pedekatan Huntara bersifat mandiri dengan konsep ramah lingkungan, efesien waktu, aman, dan nyaman (gambar 8).

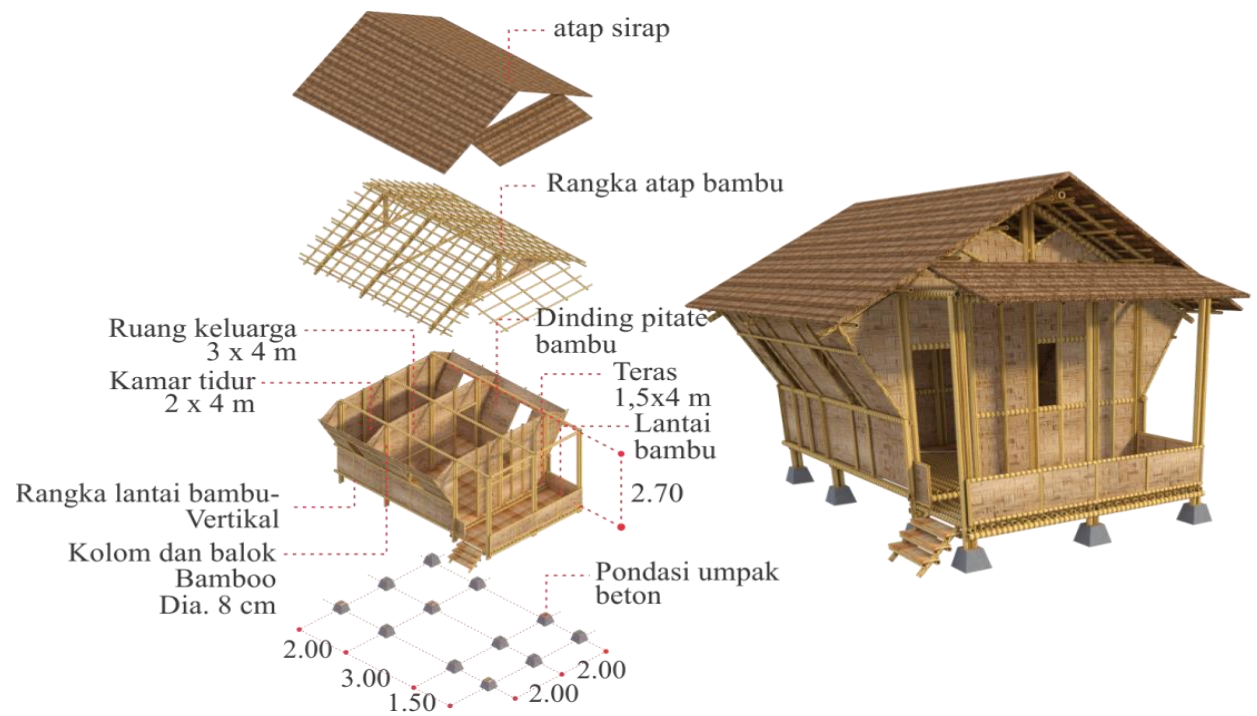

Gambar 8. Model huntara mandiri KUN (sumber: KUN)

Konsep bambu ini juga dipengaruhi oleh latar belakang lembaga donor yaitu IMC yang memiliki visi misi ramah lingkungan dan menolak adanya penebangan pohon secara massif pada setiap program hunian. Proses implementasi program huntara KUN dilakukan dengan partisipasi warga dari proses awal hingga akhir (gambar 9). Awal kegiatan warga diberikan edukasi mengenai bambu melalui pelatihan pengolahan pengawetan bambu dan pelatihan tukang serta sosialisasi desain huntara. Pelatihan tersebut dilakukan secara kelompok yang telah dibentuk oleh warga. Kegiatan ini menjadi hal yang sangat penting dalam program KUN agar tercapainya partisipatif, edukatif dan ketahanan material bambu. Untuk mengetahui jumlah material yang dibutuhkan, warga membuat miniatur Huntara. Setelah mengetahui jumlah material yang dibutuhkan, kemudian dilakukan proses pengelolaan pengawetan bambu.

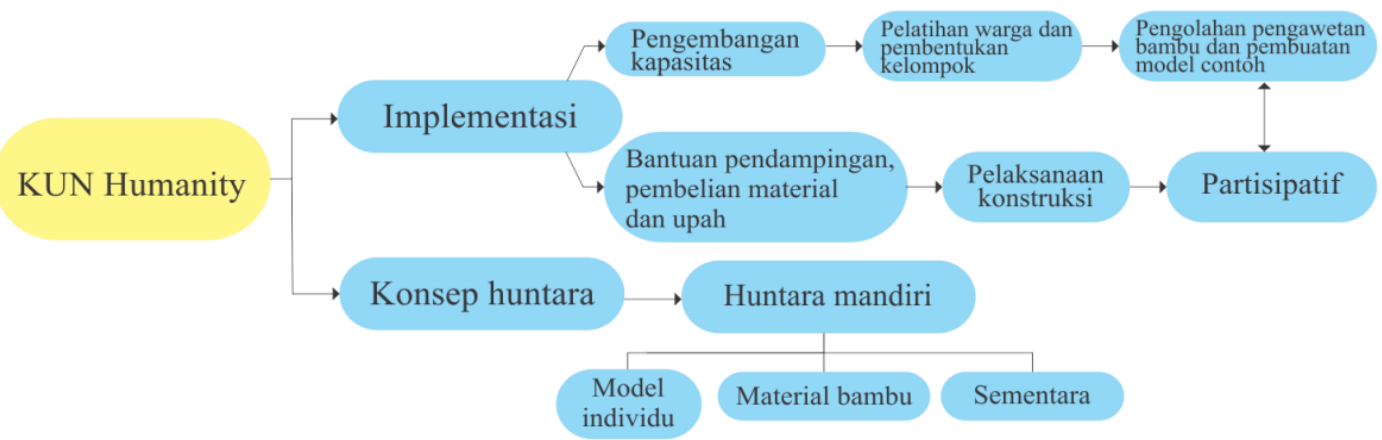

Gambar 9. Tahapan pendekatan dan implementasi lembaga Habitat 
Jumlah bambu yang dibutuhkan sebanyak 238 batang untuk satu unit Huntara, maka kebutuhan total bambu sekitar 12.376 batang. Jenis bambu yang digunakan adalah bambu Apus atau bambu betung sebagai struktur utama, namun jenis ini jarang ditemukan di Desa Namo yang akhirnya pengadaan melalui desa yang bersebalahan. Untuk komponen dinding menggunakan bambu anyam atau disebut pitate serta komponen atap menggunakan rumbiah. Sebelum warga membangun huntara, KUN mendirikan satu unit rumah contoh bersama warga.

Pada pelaksanaan konstruksi, warga tetap mengacu pada modul denah yang telah disepakati, walaupun realisasainya beberapa warga dapat mengubah sesuai keinginannya, meskipun terdapat juga dari beberapa keluarga tidak menambahkan ruang dapur yang terpaksa harus memasak di hunian sebelumnya. Konsep Huntara KUN menggunakan sistem panggung dan knock down dengan menggunakan mur baut sehingga memiliki fleksibilitas tinggi ketika gempa.

Selain pengetahuan yang didapat, warga juga diberikan peluang ekonomi selama proses pelaksanaan huntara. KUN membuat sistem upah terhadap warga yang terlibat dalam pelaksanaan, seperti tukang maupun material hasil dari pengolahan warga agar menimbulkan antusias dalam mengikuti proses tersebut. Warga yang telah mendapat pelatihan tukang lebih diutamakan dalam proses konstruksi. Manfaat dari mekanisme ini antara lain warga memahami cara pengolahan bambu, meningkatkan semangat kolaborasi, meningkatkan keterampilan teknis mereka, memperkuat kesadaran lingkungan dan model hunian bambu dapat mendorong pengrajin di desa lain untuk memasok program dengan pitting (dinding bambu) dan atap jerami.

\section{Komparasi Model Huntara}

Komparasi antar lembaga pemerintahan dan NGO pada objek penelitian dilakukan berdasarkan 23 variabel yang mengacu pada hasil keputusan Gubernur Sulawesi Tengah No.369/476/Dis.Sos.G.ST/2018 tentang pedoman penyediaan hunian sementara oleh Lembaga non pemerintah bagi korban bencana alam di Provinsi Sulawesi Tengah (tabel 2). Keputusan tersebut merupakan hasil pembahasan antara lembaga pemerintah dan NGO yang merujuk pada panduan respon kemanusian dan panduan shelter yang selama ini dijadikan acuan.

Tabel 1. Komparasi model huntara berdasarkan empat lembaga.

\begin{tabular}{|c|c|c|c|c|}
\hline \multirow{2}{*}{ Variabel } & \multicolumn{4}{|c|}{ Lembga Pemerintahan/NGO } \\
\hline & Kementrian PUPR & CRS & HABITAT & KUN \\
\hline Jenis intervensi & $\begin{array}{l}\text { Hunian } \\
\text { sementara/Temporary } \\
\text { housing (model kolektif) }\end{array}$ & $\begin{array}{l}\text { Hunian } \\
\text { transisi/Transitional } \\
\text { shelter, Hunian } \\
\text { inti/Core shelter } \\
\text { (model mandiri) } \\
\end{array}$ & $\begin{array}{l}\text { Hunian } \\
\text { sementara/Temporary } \\
\text { shelter (model } \\
\text { mandiri) }\end{array}$ & $\begin{array}{l}\text { Hunian } \\
\text { sementara/Temporar } \\
\text { y shelter (model } \\
\text { mandiri) }\end{array}$ \\
\hline Kisaran Biaya & $300-450$ juta (per unit) & $15-20$ juta & $17.5-22.5$ juta & $8-10$ juta \\
\hline Daya tahan & $\begin{array}{l}\text { Material bertahan lebih } \\
\text { dari } 2 \text { tahun }\end{array}$ & $\begin{array}{l}\text { Material bertahan lebih } \\
\text { dari } 2 \text { tahun }\end{array}$ & $\begin{array}{l}\text { Material bertahan lebih } \\
\text { dari } 2 \text { tahun }\end{array}$ & $\begin{array}{l}\text { Material relative } \\
\text { bertahan 2-20 tahun }\end{array}$ \\
\hline $\begin{array}{l}\text { Luas lantai } \\
(3.5 \mathrm{~m} 2 / \mathrm{org})\end{array}$ & $\begin{array}{l}17.28 \mathrm{~m} 2 \text { (luas lantai) } / 5 \\
(\max 5 \mathrm{org})=3.45 \mathrm{~m} 2\end{array}$ & $\begin{array}{l}24 \mathrm{~m} 2 \text { (luas lantai) } / 5 \\
(\max 5 \text { org })=4.8 \mathrm{~m} 2\end{array}$ & $\begin{array}{l}20 \mathrm{~m} 2(\text { luas lantai }) / 5 \\
(\max 5 \text { org })=4 \mathrm{~m} 2\end{array}$ & $\begin{array}{l}24 \mathrm{~m} 2(\text { luas lantai }) / 5 \\
(\max 5 \mathrm{org})=4.8 \mathrm{~m} 2\end{array}$ \\
\hline $\begin{array}{l}\text { Ketahanan } \\
\text { terhadap } \\
\text { bencana }\end{array}$ & $\begin{array}{l}\text { Model Huntara memiliki } \\
\text { fleksibilitas tinggi } \\
\text { terhadap gempa, sistem } \\
\text { panggung meminimalisir } \\
\text { banjir. Namun angina }\end{array}$ & $\begin{array}{l}\text { Sturktur kayu secara } \\
\text { alami tahan terhadap } \\
\text { gempa sesuai dengan } \\
\text { sifatny, pondasi } \\
\text { menerus dapat } \\
\text { terancam banjir }\end{array}$ & $\begin{array}{l}\text { Model Huntara } \\
\text { memiliki fleksibilitas } \\
\text { tinggi terhadap gempa, } \\
\text { sistem panggung } \\
\text { meminimalisir banjir. } \\
\text { Namun angin kencang }\end{array}$ & $\begin{array}{l}\text { Model Huntara } \\
\text { memiliki fleksibilitas } \\
\text { tinggi terhadap } \\
\text { gempa, sistem } \\
\text { panggung } \\
\text { meminimalisir }\end{array}$ \\
\hline
\end{tabular}




\begin{tabular}{|c|c|c|c|c|}
\hline \multirow{2}{*}{ Variabel } & \multicolumn{4}{|c|}{ Lembga Pemerintahan/NGO } \\
\hline & Kementrian PUPR & CRS & HABITAT & KUN \\
\hline & $\begin{array}{l}\text { kencang dapat } \\
\text { mengancam Huntara. }\end{array}$ & $\begin{array}{l}\text { tergantung lokasi, kuat } \\
\text { terhadap ancaman } \\
\text { angin kencang. }\end{array}$ & $\begin{array}{l}\text { dapat mengancam } \\
\text { Huntara. }\end{array}$ & $\begin{array}{l}\text { banjir. Namun } \\
\text { angina kencang } \\
\text { dapat mengancam } \\
\text { Huntara. }\end{array}$ \\
\hline $\begin{array}{l}\text { Durasi } \\
\text { pelaksanaan } \\
\text { (per unit) }\end{array}$ & 1 bulan & $\begin{array}{l}3-5 \text { bulan (termasuk } \\
\text { pelatihan dan } \\
\text { konstruksi) }\end{array}$ & $\begin{array}{l}1 \text { bulan (termasuk } \\
\text { pelatihan dan } \\
\text { konstruksi) }\end{array}$ & $\begin{array}{l}3-5 \text { bulan } \\
\text { (termasuk pelatihan } \\
\text { dan konstruksi) }\end{array}$ \\
\hline Privasi & $\begin{array}{l}\text { Bilik ruang tidak } \\
\text { memiliki ruang privat } \\
\text { keluarga }\end{array}$ & $\begin{array}{l}\text { Memiliki } 1 \text { hingga } 2 \\
\text { ruang privasi } \\
\text { tergantung kebutuhan } \\
\text { keluarga }\end{array}$ & $\begin{array}{l}\text { Memiliki } 1 \text { ruang } \\
\text { privasi }\end{array}$ & $\begin{array}{l}\text { Memiliki } 1 \text { ruang } \\
\text { privasi }\end{array}$ \\
\hline $\begin{array}{l}\text { Akses } \\
\text { disabilitas }\end{array}$ & $\begin{array}{l}\text { Tidak memiliki akses } \\
\text { disabilitas }\end{array}$ & $\begin{array}{l}\text { Fleksibel terhadap } \\
\text { kebutuhan anggota } \\
\text { keluarga }\end{array}$ & $\begin{array}{l}\text { Fleksibel terhadap } \\
\text { kebutuhan anggota } \\
\text { keluarga }\end{array}$ & $\begin{array}{l}\text { Fleksibel terhadap } \\
\text { kebutuhan anggota } \\
\text { keluarga }\end{array}$ \\
\hline Plafon & $\begin{array}{l}\text { Memiliki plafon elevasi } \\
3 \mathrm{~m} \text { dari lantai }\end{array}$ & Tidak memiliki plafon & Tidak memiliki plafon & $\begin{array}{l}\text { Tidak memiliki } \\
\text { plafon }\end{array}$ \\
\hline Konteks lokal & $\begin{array}{l}\text { Model bersifat } \\
\text { konvensional }\end{array}$ & $\begin{array}{l}\text { Beberapa model } \\
\text { memiliki konteks lokal } \\
\text { tergantung tingkat } \\
\text { keahlian }\end{array}$ & $\begin{array}{l}\text { Model bersifat } \\
\text { konvensional }\end{array}$ & $\begin{array}{l}\text { Model memiliki } \\
\text { konteks lokal } \\
\text { terutama } \\
\text { penggunaan material }\end{array}$ \\
\hline $\begin{array}{l}\text { Air bersih dan } \\
\text { sanitasi }\end{array}$ & $\begin{array}{l}\text { Tersedia fasilitas air } \\
\text { bersih dan latrine yang } \\
\text { sifatnya umum }\end{array}$ & $\begin{array}{l}\text { Terdapat latrine privat } \\
\text { yang terpisah dari } \\
\text { hunian }\end{array}$ & $\begin{array}{l}\text { Tersedia fasilitas air } \\
\text { bersih dan latrine yang } \\
\text { sifatnya umum }\end{array}$ & $\begin{array}{l}\text { Tersedia fasilitas air } \\
\text { bersih dan latrine } \\
\text { yang sifatnya umum }\end{array}$ \\
\hline Fasilitas masak & $\begin{array}{l}\text { Tersedia fasilitas dapur } \\
\text { yang sifatnya umum }\end{array}$ & $\begin{array}{l}\text { Tidak tersedia ruang } \\
\text { dapur }\end{array}$ & $\begin{array}{l}\text { Tidak tersedia ruang } \\
\text { dapur }\end{array}$ & $\begin{array}{l}\text { Tidak tersedia ruang } \\
\text { dapur }\end{array}$ \\
\hline Lokasi & $\begin{array}{l}\text { Pemilihan lokasi yang } \\
\text { berada di zona aman } \\
\text { sesuai rekomendasi } \\
\text { Badan Geologi, dan } \\
\text { persetujuan pemilik } \\
\text { tanah }\end{array}$ & $\begin{array}{l}\text { Pemilihan lokasi di } \\
\text { tanah milik sendiri } \\
\text { atau lokasi yang } \\
\text { sebelumnya terkena } \\
\text { gempa, dapat juga } \\
\text { tanah pinjaman/sewa } \\
\text { dengan syarat surat } \\
\text { pinjaman/sewa }\end{array}$ & $\begin{array}{l}\text { Pemilihan lokasi di } \\
\text { tanah milik sendiri } \\
\text { atau lokasi yang } \\
\text { sebelumnya terkena } \\
\text { gempa, dapat juga } \\
\text { tanah pinjaman/sewa } \\
\text { dengan syarat surat } \\
\text { pinjaman/sewa }\end{array}$ & $\begin{array}{l}\text { Pemilihan lokasi di } \\
\text { tanah milik sendiri } \\
\text { atau lokasi yang } \\
\text { sebelumnya terkena } \\
\text { gempa, dapat juga } \\
\text { tanah pinjaman/sewa } \\
\text { dengan syarat surat } \\
\text { pinjaman/sewa }\end{array}$ \\
\hline Ventilasi & $\begin{array}{l}\text { Terpenuhi (lebih dari } 1 \\
\mathrm{~m}^{2} \text { ) }\end{array}$ & $\begin{array}{l}\text { Terpenuhi (lebih dari } 1 \\
\mathrm{~m}^{2} \text { ) }\end{array}$ & $\begin{array}{l}\text { Terpenuhi (lebih dari } 1 \\
\mathrm{~m}^{2} \text { ) }\end{array}$ & $\begin{array}{l}\text { Terpenuhi (lebih dari } \\
1 \mathrm{~m}^{2} \text { ) }\end{array}$ \\
\hline Drainase & $\begin{array}{l}\text { Tidak ada drainase dan } \\
\text { tidak terhubung oleh } \\
\text { drainase kota }\end{array}$ & Tidak ada drainase & Tidak ada drainase & Tidak ada drainase \\
\hline Ruang Terbuka & $\begin{array}{l}\text { Tersedia ruang terbuka } \\
\text { di kawasan Huntara }\end{array}$ & - & - & - \\
\hline $\begin{array}{l}\text { Ketinggian } \\
\text { ruang minimal } \\
2.4 \mathrm{~m}\end{array}$ & Tinggi ruang $3 \mathrm{~m}$ & $\begin{array}{l}\text { Tinggi ruang } 2.6 \mathrm{~m}-3 \\
\mathrm{~m}\end{array}$ & $\begin{array}{l}\text { Tinggi ruang } 2.3 \mathrm{~m} \\
\text { (tidak mencukupi } 2.4 \\
\mathrm{~m} \text { ) }\end{array}$ & Tinggi ruang $2.7 \mathrm{~m}$ \\
\hline Penerangan & $\begin{array}{l}\text { Terdapat titik lampu di } \\
\text { setiap ruangan }\end{array}$ & $\begin{array}{l}\text { Terdapat titik lampu di } \\
\text { setiap ruangan }\end{array}$ & $\begin{array}{l}\text { Terdapat titik lampu di } \\
\text { setiap ruangan }\end{array}$ & $\begin{array}{l}\text { Terdapat titik lampu } \\
\text { di setiap ruangan }\end{array}$ \\
\hline $\begin{array}{l}\text { Keamanan } \\
\text { penggunaan } \\
\text { material }\end{array}$ & $\begin{array}{l}\text { Tidak terdapat } \\
\text { menggunakan asbestos } \\
\text { dan cat timbal }\end{array}$ & $\begin{array}{l}\text { Tidak terdapat } \\
\text { menggunakan asbestos } \\
\text { dan cat timbal }\end{array}$ & $\begin{array}{l}\text { Tidak terdapat } \\
\text { menggunakan asbestos } \\
\text { dan cat timbal }\end{array}$ & $\begin{array}{l}\text { Tidak terdapat } \\
\text { menggunakan } \\
\text { asbestos dan cat } \\
\text { timbal }\end{array}$ \\
\hline
\end{tabular}




\begin{tabular}{|c|c|c|c|c|}
\hline \multirow{2}{*}{ Variabel } & \multicolumn{4}{|c|}{ Lembga Pemerintahan/NGO } \\
\hline & Kementrian PUPR & CRS & HABITAT & KUN \\
\hline $\begin{array}{l}\text { Ramah } \\
\text { lingkungan } \\
\text { (tidak } \\
\text { menggunakan } \\
\text { bahan dari } \\
\text { kawasan yang } \\
\text { dilindungi) }\end{array}$ & $\begin{array}{l}\text { Seluruh penggunaan } \\
\text { material berasal dari } \\
\text { bahan fabrikasi }\end{array}$ & $\begin{array}{l}\text { Mayoritas penggunaan } \\
\text { material kayu lokal } \\
\text { yang sebagian berasal } \\
\text { dari kawasan hutan } \\
\text { yang dilindungi }\end{array}$ & $\begin{array}{l}\text { Mayoritas penggunaan } \\
\text { material berasal dari } \\
\text { bahan fabrikasi }\end{array}$ & $\begin{array}{l}\text { Mayoritas } \\
\text { penggunaan material } \\
\text { bambu berasal dari } \\
\text { desa sekitar yang } \\
\text { memiliki populasi } \\
\text { banyak }\end{array}$ \\
\hline $\begin{array}{l}\text { Kelengkapan } \\
\text { isi rumah }\end{array}$ & $\begin{array}{l}\text { Terdapat lemari pakaian, } \\
\text { tempat tidur dan fasilitas } \\
\text { memasak }\end{array}$ & $\begin{array}{l}\text { Terdapat perlengkapan } \\
\text { rumah tangga yang } \\
\text { sebelumnya digunakan }\end{array}$ & $\begin{array}{l}\text { Terdapat perlengkapan } \\
\text { rumah tangga yang } \\
\text { sebelumnya digunakan }\end{array}$ & $\begin{array}{l}\text { Terdapat } \\
\text { perlengkapan rumah } \\
\text { tangga yang } \\
\text { sebelumnya } \\
\text { digunakan } \\
\end{array}$ \\
\hline $\begin{array}{l}\text { Kualitas } \\
\text { material }\end{array}$ & $\begin{array}{l}\text { Kualitas material rangka } \\
\text { baja ringan berstandar } \\
\text { SNI (Standar Nasional } \\
\text { Indonesia) }\end{array}$ & $\begin{array}{l}\text { Kualitas material } \\
\text { menggunakan kayu } \\
\text { klas II (material } \\
\text { tergolong kuat dan } \\
\text { aman) }\end{array}$ & $\begin{array}{l}\text { Kualitas material } \\
\text { rangka baja ringan } \\
\text { berstandar SNI } \\
\text { (Standar Nasional } \\
\text { Indonesia) }\end{array}$ & $\begin{array}{l}\text { Kualitas material } \\
\text { bambu berjenis avo } \\
\text { (jenis bambu tebal) } \\
\text { serta melalui } \\
\text { pengolahan } \\
\text { pengawetan }\end{array}$ \\
\hline Keamanan & $\begin{array}{l}\text { Setiap ruang tersedia alat } \\
\text { pengunci }\end{array}$ & $\begin{array}{l}\text { Setiap ruang tersedia } \\
\text { alat pengunci }\end{array}$ & $\begin{array}{l}\text { Setiap ruang tersedia } \\
\text { alat pengunci }\end{array}$ & $\begin{array}{l}\text { Setiap ruang tersedia } \\
\text { alat pengunci }\end{array}$ \\
\hline Akses & $\begin{array}{l}\text { Kawasan memiliki ruang } \\
\text { parkir dan terhubung } \\
\text { oleh akses jalan umum }\end{array}$ & $\begin{array}{l}\text { Terhubung oleh akses } \\
\text { jalan umum }\end{array}$ & $\begin{array}{l}\text { Terhubung oleh akses } \\
\text { jalan umum }\end{array}$ & $\begin{array}{l}\text { Terhubung oleh } \\
\text { akses jalan umum }\end{array}$ \\
\hline
\end{tabular}

Berdasarkan komporasi, model huntara dari tiap lembaga secara umum telah mengikuti standar yang telah ditentukan sesuai konteks fase transisi, walaupun beberapa model huntara belum memenuhi variabel standar seperti biaya, durasi pelaksanaan, plafon, ketinggian ruang, dan lingkungan. Variabel ini juga memiliki urgenitas tinggi terhadap penerapan isu keberlanjutan. Penggunaan biaya besar menjadi tidak relevansi terhadap program huntap dan dana stimulan sehingga dapat menimbulkan kesenjangan sosial. Material fabrikasi memiliki keunggulan pada durasi pelaksanaan dengan metode pembangunan langsung oleh tukang terlatih, sementara material lokal dapat melibatkan masyarakat lokal terutama pemiliknya. Plafon dan ketinggian ruang sangat mempengaruhi kenyamanan pemiliknya, sehingga dibeberapa kasus model huntara seperti huntara PUPR dan Habitat ditinggalkan oleh pemiliknya di siang hari akibat kepanasan. Ramah lingkungan pada konteks penggunaan material juga menjadi kendala terutama di masa sekarang yakni masa pemanasan global. Material kayu secara peforma sangat baik, namun perlu manajemen agar masyarkat teredukasi dan tidak masif dalam penggunaannya

\section{Respon Penyintas}

Respon terhadap kebutuhan bertempat tinggal sementara meliputi pemenuhan terhadap kebutuhan, untuk bertempat tinggal sementara, anggota keluarga yang dapat tertampung, serta barang yang dapat tertampung di huntara (gambar10). Berdasarkan hasil yang diperoleh dari faktor pemenuhan kebutuhan bertempat tinggal sementara, lembaga KUN memiliki nilai tertinggi $(2,6)$. Pada faktor tertampungnya seluruh anggota keluarga huntara dan tertampungnya seluruh barang dihuntara, lembaga CRS memiliki nilai yang paling tinggi $(3,0)$. 


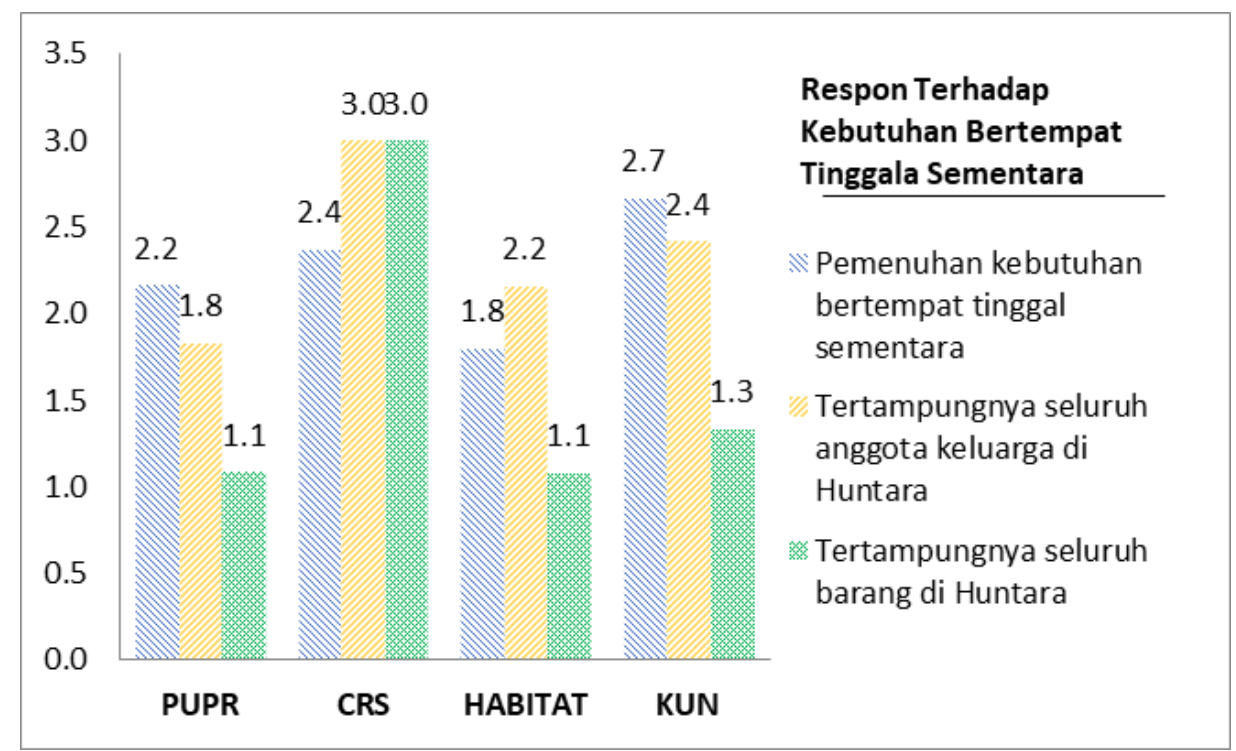

Gambar 10. Diagram respon terhadap kebutuhan bertempat tinggal sementara

Respon terhadap rasa aman dan nyaman meliputi rasa keselamatan, rasa aman melindungi harta benda, dan rasa nyaman. Berdasarkan hasil yang diperoleh pada respon terhadap rasa aman dan nyaman lembaga CRS memiliki nilai tertinggi pada masing-masing faktor (gambar 11). Pada lembaga KUN pada faktor nyaman tinggal di huntara memiliki jumlah nilai yang sama dengan lembaga CRS (2,4 poin). Sehingga pada respon terhadap rasa aman dan nyaman di dominasi oleh huntara dari lembaga CRS.

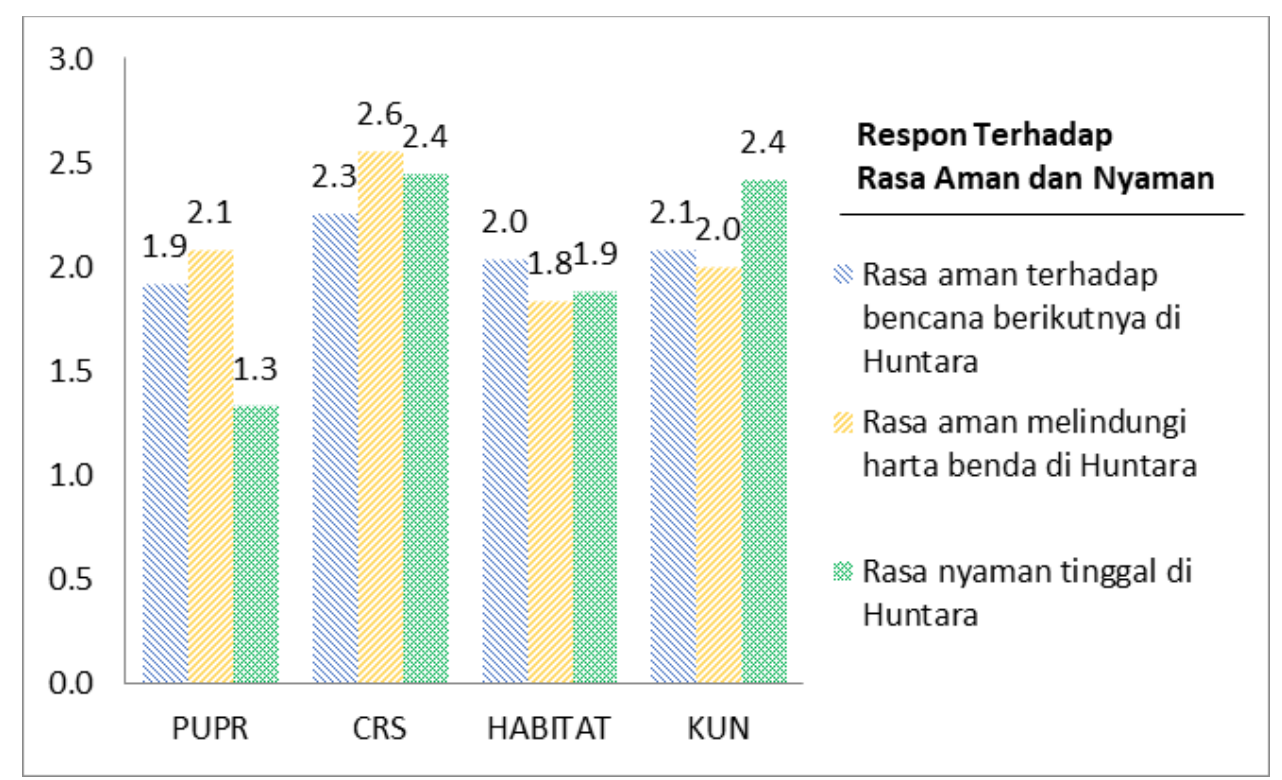

Gambar 11. Diagram respon rasa aman dan nyaman

Respon terhadap keinginan meliputi harapan terhadap huntara. Penilaian dilakukan dengan cara menghitung jumlah persentase jawaban berdasarkan pilihan berupa keselamatan, keamanan, kenyamanan, dan lainnya (gambar 12). Berdasarkan data tersebut persentasi nilai tertinggi harapan penyintas terhadap huntara dari tiap lembaga adalah faktor keselamatan, yakni terselamatkan kebutuhan dasar hunian saat fase darurat menuju transisi. Keselamatan juga mengenai struktur huntara yang aman terhadap ancaman bencana berikutnya. Selanjutnya prioritas kedua adalah faktor keamanan yakni penyintas dapat melindungi harta bendanya. 
Faktor kenyamanan menjadi prioritas ketiga yakni penghuni merasakan nyaman dan betah terhadap ruang dalam serta lingkungan sekitar huntara.

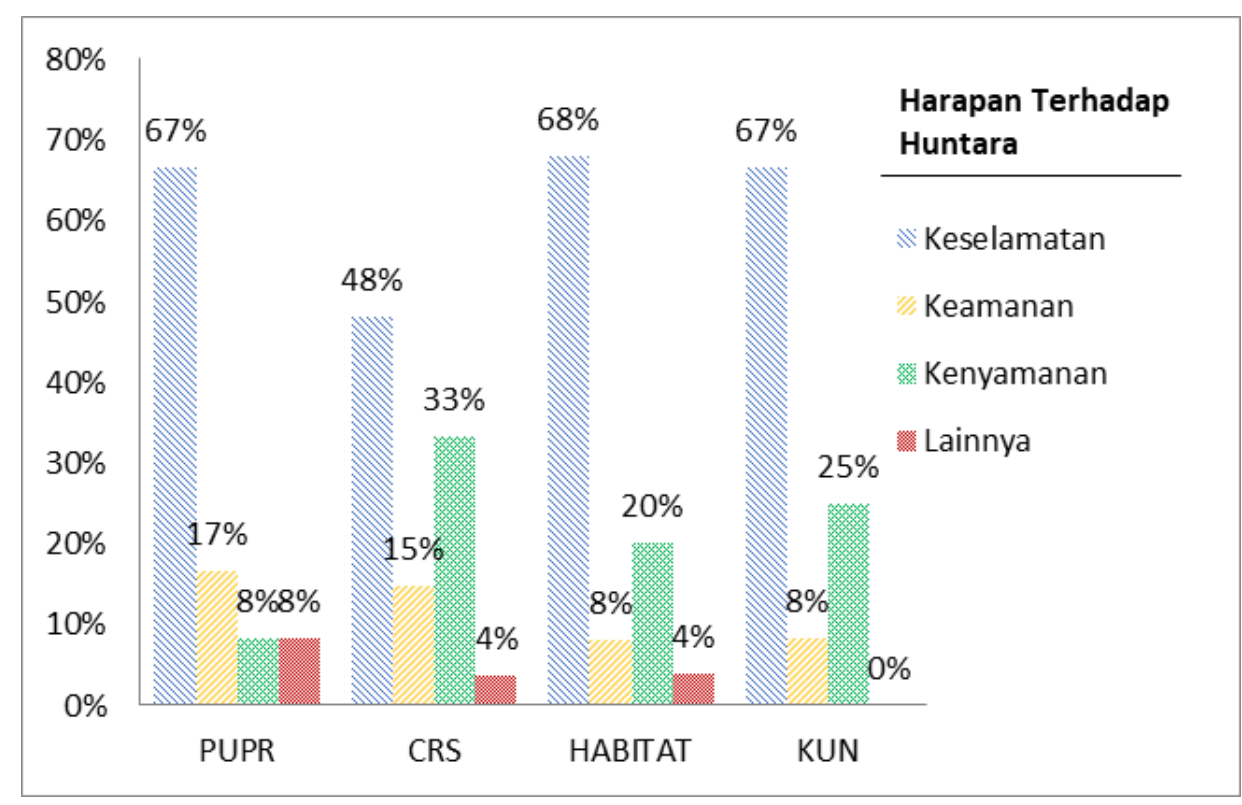

Gambar 12. Diagram harapan terhadap huntara

Dari tiap lembaga menunjukkan lembaga CRS dan KUN memenuhi semua variabel standar huntara, sedangkan pada komparasi penilaian respon penyintas menunjukkan lembaga CRS mendominasi poin tertinggi. Pemanfaatan material lokal kayu dan bambu dalam membangun huntara memberikan peluang ekonomi bagi penyintas dan dinilai efektif berdasarkan pengalaman bencana. Penggunaan material tersebut memberikan kemudahan dalam proses konstruksi terutama sambungan struktur yang dapat disesuaikan dengan keahlian tukang setempat dan sifat material yang dapat meredam panas sehingga memberikan kenyamanan dalam ruang. Luas hunian yang melebihi standar huntara, memiliki ruang privasi, serta relevan untuk pengembangan ternyata memberikan kepuasan bagi penghuninya. Pendekatan secara bantuan tunai dan partisipatif memiliki tantangan tersendiri karena membutuhkan waktu pelaksanaan yang lama. Faktor lingkungan dapat menjadi perhatian yang serius dalam melakukan pendekatan ini terutama penggunaan kayu yang secara masif.

Model huntara mandiri atau individu yang dibangun secara tipikal mempercepat proses konstruksi serta memudahkan dalam pendampingan. Penggunaan material fabrikasi yang seragam perlu mempertimbangkan pasokan yang tersedia sehingga tidak mempengaruhi kecepatan pembanguna, namun struktur huntara dengan material fabrikasi memberikan kesan bagi penyinitas bersifat sementara sehingga tidak dapat dikembangkan menjadi hunian inti atau permanen. Ketinggian hunian yang minim serta tidak adanya plafon membuat tidak nyaman pada siang hari, sehingga penerimaan yang rendah dari penyintas.

Pemerintah memiliki kemampuan besar dalam penyediaan huntara juga memiliki penerimaan yang rendah bagi penyintas. Model komunal serta tidak tersedianya ruang privasi menjadikan penyintas kurang nyaman, walaupun secara struktur aman terhadap gempa selanjutnya. Model huntara tersebut lebih efektif di fase darurat pada kasus bencana likuifaksi atau tsunami yang dapat menghilangkan rumah. Dengan kemampuan finansial, pemerintah dapat membuat model huntara yang sesuai konteks.

Sturuktur dan luas ruang menjadi standar penerimaan penyintas. Konsep model huntara yang memiliki tingkat sturuktur yang kuat dan mudah untuk melakukan pengembangan menjadikan modal utama bagi penyintas menuju fase rehabilitasi. Pemahaman struktur pada konteks lokal Sigi juga mempengaruhi penerimaan yang selama ini terbiasa dengan material 
kayu. Bambu secara performa terbilang baik untuk kenyamanan, namun sulit untuk dikembangkan menuju permanen. Ruang luas memberikan kepuasan bagi penghuninya untuk memasukkan barang-barang yang telah ada sebelumnya. Adanya ruang privasi serta ruang pendukung lainnya secara otomatis membuat martabat penyintas menjadi baik yang sebelumnya penuh rasa trauma.

\section{SIMPULAN DAN SARAN}

Penelitian ini menunjukkan bahwa pendekatan model huntara mandiri dan implementasi bantuan uang tunai berbasis partisipatif yang dilakukan lembaga CRS lebih efektif untuk pemulihan dibandingkan pendekatan model huntara lembaga lainnya. Terlibatnya penyintas dalam memanajemen keuangan serta pengelolaan ruang hunian memberikan kesesuaian konteks penyintas dan menjadi modal besar untuk pemulihan menuju fase permanen. Pendekatan yang dilakukan pemerintah dan NGO memiliki perbedaan yang signifikan, yaitu pemerintah dengan cara mengintervensi langsung proses konsep model huntara hingga implementasinya yang menerapkan huntara kolektif, sedangkan NGO dengan cara berbasis partisipatif berupa pelibatan penyintas dari proses awal hingga implementasinya yang menerapkan huntara mandiri atau individu. Pemenuhan huntara di fase transisi menjadi parameter pemulihan penyintas dari keterpurukan, rasa trauma, serta mengangkat martabat, namun pemenuhan yang tidak efektif tanpa melihat konteks kebutuhan penyintas dan lokalitas dapat berpotensi kerentanan sehingga menjadi permasalahan. Intervensi penyintas terhadap huniannya secara keseluruhan menjadikan modal besar hunian tumbuh sesuai prilaku penggunanya.

Pendekatan huntara secara mandiri dengan berbasis uang tunai menjadi hal pembelajaran sekaligus dapat dijadikan acuan program pemenuhan huntara terutama pada kasus gempabumi. Tumbuh kembangnya hunian dari pendekatan ini menjadi salah satu aspek yang dapat dijadikan penelitian selanjutnya, sehingga dapat dikorelasikan efesiensi dan efektivitas program hunian tetap pemerintah yang notabanenya memerlukan pembiayaan secara masif. Fase transisi menuju rehabilitasi memiliki durasi waktu yang fleksibel dapat 2 tahun bahkan lebih, sehingga lembaga perlu mempertimbangkan pendekatan model huntara serta implementasinya guna menghadapi bencana yang akan datang.

\section{DAFTAR RUJUKAN}

Barakat, S. (2003). Housing reconstruction after conflict and disaster. Humanitarian Practice Network (HPN), 44(43), 1-37. Retrieved from www.odihpn.org

Badan Geologi. (2018:5). Di balik Pesona Palu Bencana Melanda Geologi Menata.

Bashawri, A., Garrity, S., \& Moodley, K. (2014). An Overview of the Design of Disaster Relief Shelters. Procedia Economics and Finance, 18(September), 924-931. https://doi.org/10.1016/S2212-5671(14)01019-3

Batchelor, V. (2011). Tarpaulins, transitional shelters or permanent houses : how does the shelter assistance provided affect the recovery of communities after disaster? Two case studies in Indonesia: Victoria Batchelor Centre for Development and Emergency Practice ( CENDEP.

BMKG, (2018) Press Release NO: UM.505/9/D3/IX/2018. https://doi.org/10.1051/matecconf/201712107005

Buletin Suara Komunitas. (2018:1). Suara Komunitas Respons Gempa Sulawesi Tengah.

Carrasco, S., \& O'Brien, D. (2018:612). The Role of Humanitarian Agencies in Reconstruction and Development of Disaster Affected Communities in Japan and the Philippines. 
Procedia Engineering,

212(2017),

606-613. https://doi.org/10.1016/j.proeng.2018.01.078

Dewi Wulansari, M. A., \& Wihardyanto, D. (2017:92-93). Metodologi Penilaian Kualitas Hunian Paska Bencana Sebagai Evaluasi Strategi Rekonstruksi: Analisis Faktual Dan Perseptual. Langkau Betang: Jurnal Arsitektur, 4(2), 89. https://doi.org/10.26418/lantang.v4i2.23272

Donohou, C. (2012:2), Strategic Planning for Post-Earthquake Temporary Housing: Best Practices. Humanitarian Aid in Complex Emergencies University of Denver. (http://www.du.edu/korbel/criic/humanitarianbriefs/hbindex.html)

Doocy, S., Gabriel, M., Collins, S., Robinson, C., \& Stevenson, P. (2006:293). Implementing cash for work programmes in post-tsunami Aceh: Experiences and lessons learned. Disasters, 30(3), 277-296. (https://doi.org/10.1111/j.0361-3666.2005.00321.x)

Faure Walker, J., \& Anna Crawford, C. (2017:229). Cash In a Housing Context: Transitional Shelter And Recovery In Japan. International Journal of Disaster Risk Reduction, 24 (November 2016), 216-231 (https://doi.org/10.1016/j.ijdrr.2017.05.018)

Félix, D., \& Famalicão, N. De. (2013:10). Guidelines to Improve Sustainability and Cultural Integration of Temporary Housin Units. 1-12. (http://repositorium.sdum.uminho.pt/bitstream/1822/24319/1/1_F\%C3\%A9lix\%20et\%2 0al.pdf)

Félix, D., Branco, J. M., \& Feio, A. (2013: 141). Temporary housing after disasters: A state of the art survey. Habitat International, 40, 136-141. (https://doi.org/10.1016/j.habitatint.2013.03.006)

Forouzandeh, A. J., Hosseini, M., \& Sadeghzadeh, M. (2008:8). Guidelines for Design of Temporary Shelters After Earthquakes Based on Community Participation. 14th World Conference on Earthquake Engineering (14WCEE), (1991).

Hatmoko, J. H. (2015). Survei Minat Dan Motivasi Siswa Putri Terhadap Mata Pelajaran Penjasorkes Di Smk Se-Kota Salatiga Tahun 2013. E-Jurnal Physical Education, Sport(Health and Recreation), 1729-1736. https://doi.org/10.15294/active.v4i4.4855

Hibatullah Hindami N A, Tazkia Agung Fuadi, Dimas Rahmatullah, Muhammad Kholif L. W. P. (2014:35). Kriteria Desain Alih Fungsi Huntara Menjadi Hunian Permanen Korban Bencana Merapi. (1), 35-40.

IFRC. (2013). Post-disaster shelter : Ten designs. Retrieved from www.ifrc.org

Kareba Palu Koro. (2019:2). Kabar penanganan bencana Sulawesi Tengah

Keputusan Gubernur Sulawesi Tengah No.369/476/Dis.Sos.G.ST/2018. (2018:4-7). Pedoman Penyediaan Hunian Sementara Oleh Lembaga Non Pemerintah Bagi Korban Bencana Alam di Provinsi Sulawesi Tengah

Leon, E., Kelman, I., Kennedy, J., \& Ashmore, J. (2009:247). Capacity Building Lessons From a Decade of Transitional Settlement And Shelter. International Journal of Strategic Property Management, 13(3), 247-265. (https://doi.org/10.3846/1648715X.2009.13.247-265)

Palang Merah Indonesia (PMI) (2019:2.3). Panduan shelter untuk kemanusiaan (edisi bahasa Indonesia)

Pemerintah Provinsi Sulawesi Tengah. (2019). Laporan Finalisasi Data dan Informasi Bencana Gempa Bumi , Tsunami dan Likuifaksi di Sulawesi Tengah Per Tanggal 20 Des 2018. 
14.

Silva, J. da. (2010). Lessons from Aceh-Key Considerations in Post-Disaster Reconstruction. Post-Disaster Reconstruction: Lessons from Aceh, 227-234. https://doi.org/10.4324/9781849775137

Sub Klaster Sulawesi Tengah. (2019). Progres Huntara di Kabupaten Dan Kota Provinsi Sulawesi Tengah.

Supriyati. (2015:5-6). Metode Penelitian Gabungan (Mixed Methods). Widyaiswara BDK,124.

(http://bdksurabayakemenag.di/p3/data/uploaded/dokumen/MIXED_METHOD_NINIK _edit.pdf)

Thapa, R., Rijal, H. B., \& Shukuya, M. (2018:342). Field Study On Acceptable Indoor Temperature In Temporary Shelters Built In Nepal After Massive Earthquake 2015. 135(February), 330-343. (https://doi.org/10.1016/j.buildenv.2018.03.001)

The Sphere Project (2011). Piagam Kemanusiaan dan Standar- Standar Minimum dalam Respons Kemanusiaan.

Wu, J., Huang, C., Pang, M., Wang, Z., Yang, L., FitzGerald, G., \& Zhong, S. (2019:1-2). Planned Sheltering As an Adaptation Strategy To Climate Change: Lessons Learned From The Severe Flooding In Anhui Province of China in 2016. Science of the Total Environment, 694, 133586. (https://doi.org/10.1016/j.scitotenv.2019.133586)

Wulansari, M. A. D. (2014:27). Kepuasan Huni dan Perubahan Hunian pada Rumah Paska Bencana Erupsi Merapi-Kasus: Hunian tetap Pagerjurang, Cangkringan, Sleman, D.I. Yogyakarta. (1987), 27-33

Yu, Y., Long, E., Shen, Y., \& Yang, H. (2016:174). Assessing the thermal performance of temporary shelters. Procedia Engineering, 159(June), 174-178. https://doi.org/10.1016/j.proeng.2016.08.152

Zea Escamilla, E., \& Habert, G. (2015:692). Global or local construction materials for postdisaster reconstruction? Sustainability assessment of 20 post-disaster shelter designs. Data in Brief, 4, 308-314. https://doi.org/10.1016/j.dib.2015.05.027 